\title{
Comparative Study of Vegetable Biodiversity in Terai and Hilly Belts of Chitwan, Nepal
}

\author{
Pukar Devkota* and Sharoj R. Mishra \\ Institute of Agriculture and Animal Science, Kathmandu, Nepal \\ *Corresponding Author \\ devkotapukar@gmail.com
}

\begin{abstract}
The study was conducted to assess biodiversity and conservation aspects of vegetable crops in two different geographical areas of the Chitwan district. The household survey was carried out in Kailash (hill) and Nayabasti (terai) of Chitwan. Descriptive analysis, mean comparison, correlations, and biodiversity indices were used for data analysis. On the basis of biodiversity index, evenness, the adequate number of species, and Sorenson's coefficient, open-pollinated (OP) (nonhybrid) vegetables were more diverse in hills than in terai, while hybrid vegetables are more diverse in terai than in hills. Hybrid vegetables were mostly grown in terai, where the use of chemical fertilizers and pesticides was also higher. OP vegetables dominated hilly areas. Gurung ethnic community had a significant role in the conservation of indigenous vegetable biodiversity. The primary source of seed was home storage in the case of OP vegetables in hills. However, in terai, agro-concerns were used as a significant source of seeds, followed by co-operatives. Co-operatives' involvement was high in terai as compared to hills, but the role was not significant in vegetable farming.

In contrast, assistance in vegetable farming from agriculture service provider organizations was higher in hills as compared to terai. The major problem in vegetable farming was lack of irrigation in both areas, followed by market inaccessibility in hills, whereas climate change was rising as a problem in terai. Markets of produced goods were farm gate, local markets, and distant markets. A middleman mostly did the price determination of the products. Off-season vegetable farming was not practiced in the study areas. However, off-farm vegetable production was typical in hilly areas. Indigenous and OP vegetable biodiversity has been facing various challenges despite their roles in nutrition, indigenous knowledge promotion, and food security. Hence, it is suggested to strengthen government policy toward irrigation facility development, gene bank establishment, marketing facilities, and technology transfer and develop on-farm community based intense organizations for sustainable vegetable diversity conservation.
\end{abstract}

\section{Keywords}

Vegetable biodiversity, open-pollinated, hybrid, indigenous, conservation.

\section{Introduction}

Agricultural biodiversity refers to all the components of biological diversity that are related to food, agriculture, and forestry. These components constitute agro-ecosystems as these forms of life are necessary to sustain life on the earth (IBD, 2008; UNEP, 2010). Agro-biodiversity is a sub-set of biodiversity. It comprises genetic diversity as well as crop and animal species diversity used in different agriculture systems and agroecosystems (Biala et al., 2005; Love and Spaner 2007). Cereals, legumes, vegetables, oilseeds, fruits, and medicinal plants are major crops which play a crucial role in food security and biodiversity conservation. Indigenous plants and local landraces are rich in diversity as well as able to cope with climate change. It has become essential in agriculture to cope with the impacts of climate change and to develop resilient agroecosystems (Frison 2011). The use of agricultural biodiversity for all agricultural systems can contribute to food, nutrition, livelihood 
security, as well as environmental securities for an extended period. Policy and assistance from the government for the modernization of agriculture have been promoting high yielding commercial vegetables all over the country. It, in coupling with agribusiness promotion and market access, has a widespread effect on farming communities. The commercialization of agriculture is helping farmers in increasing production, market, and income. Thus, the diverse and indigenous vegetables which have a significant role in the livelihood of small scale and marginal farmers and rural economy are under threat and demand for conservation. Therefore, the study aimed to find out the current situation of the diversity of openpollinated (all non-hybrids) and hybrid vegetables in farmers' fields of hilly and Terai areas of Chitwan district and make policy suggestions.

\section{Methodology}

The study was conducted in purposively selected Kabilas (hill) and Nayabasti (terai) areas of Chitwan district. Geographic and climatic variability in the two places helped us in categorizing the vegetable producers and collecting data more diversely. The places were selected because of high potential areas for vegetable farming due to fertile soil, a high diversity of vegetables, suitable topography, and easy road access. Data on vegetable farming were collected during summer, winter, and offseasons covering the whole year of 2018 A.D.

At first, the sampling frame was prepared by developing a list of vegetable growers of Kabila's and Nayabasti using various sources of information, such as critical informants of the study areas, district profile of District Agriculture Development Office (DADO) and village profile prepared by Rural Municipalities. Sixty farmers (each farmer has taken as a sampling unit) from each location (total 120 farmers) were selected by simple random sampling, and each sampling unit consisted of at least 50 sq.m. area (0.1 ropani) for vegetable farming. Primary data were collected by interviewing the household heads using a semi-structured questionnaire and direct crop field observation and secondary data through informal group discussions and key informants' interviews. Secondary data were also obtained from articles, reports, and books published by Nepal Agriculture
Research Council (NARC), Central Bureau of Statistics (CBS), Agro-Enterprise Center and DADO, Chitwan. The data were entered into an excel sheet, followed by coding and tabulation, and analyzed by using Statistical Package for Social Science, version 20 (SPSS v 20) and Microsoft Excel (MS-Excel 2010) Software packages.

\section{Result and Discussion}

\section{Socioeconomic information}

The majority of the respondents were male $(63.3 \%)$ in the study area. It is because most of the males were involved in economic activities, and females were restricted to household works. However, in hills, $56.6 \%$ of the respondents were female, but in terai male respondents dominated.

Similarly, in both areas, male-dominated the position of household head (73.34\%). The number of an economically active population dominated the population (50\%). In both areas, the majority of people were economically active population, followed by the age group of 5 to 15 years and 49 years and above. The average family size was significantly more abundant in hills, with an average of 7.02 members per family. Only $12.20 \%$ of the population was illiterate. As most of the people are educated, it would be easy to diffuse the knowledge about biodiversity conservation and its importance. The majority of the respondents had agriculture as a significant occupation, with $45.00 \%$ and $65.67 \%$ in hill and Terai, respectively.

The average cultivable land was 15.1 ropani per respondent farmer, and only $15.48 \%$ of the total cultivable area was under vegetable farming. In hills, only owned land was used for cultivation, whereas in terai, 1.99 ropani lands were taken on lease for farming. In hills, total cultivable land to vegetable cultivated land ratio was very high (18.51) while compared to terai (3.94), which means most of the cultivable land in hills have been used for other agricultural purposes than vegetables.

\section{Types of cultivated vegetables}

In the hills, the majority of the respondents (52) cultivated open-pollinated (OP) vegetables, and none of the farmers had cultivated only hybrid ones (Table 1). However, some of the farmers $(8$ and 37) cultivated both hybrid and OP vegetables 
in hills and terai, respectively. In contrast, there were very few farmers (7) who grew OP vegetables in terai. In hills, only 4 respondents preferred to cultivate hybrid vegetables, while 26 respondents in terai. In terai, even if only 7 farmers grew OP vegetables, 20 farmers had shown interest in growing them.
Significant vegetables grown in hills were: Potato, Cabbage, Brinjal, Broccoli, Cowpea, Snake gourd, Okra, Cucumber, Bitter gourd, Cauliflower, Pea, Chilly, Bottle gourd, Radish, Bean, Sponge gourd, Pumpkin, Tomato, Carrot, Capsicum, Taro/Cocoyam, Yam, Kohlrabi, Turnip, Beetroot, Chayote, Bethe, Amaranthus,

Table 1. Respondents preferring types of vegetables in two ecological belts.

\begin{tabular}{|c|c|c|c|c|c|c|}
\hline & & \multicolumn{3}{|c|}{ Number of respondents } & \multirow{2}{*}{ Total } & \multirow{2}{*}{ Chi-square value } \\
\hline & & Hybrid & Open Pollinated & Both & & \\
\hline \multicolumn{7}{|c|}{ Vegetables are grown } \\
\hline \multirow{2}{*}{ Belt } & Hill & 0 & 52 & 8 & 60 & \multirow{2}{*}{$69.011 * *$} \\
\hline & Terai & 16 & 7 & 37 & 60 & \\
\hline \multicolumn{7}{|c|}{ Vegetables preferred } \\
\hline \multirow{2}{*}{ Belt } & Hill & 4 & 53 & 3 & 60 & \multirow[t]{2}{*}{$38.169^{* *}$} \\
\hline & Terai & 26 & 20 & 14 & 60 & \\
\hline
\end{tabular}

Low productivity and lack of high yielding varieties under rice-based cropping systems are significant reasons behind the non-preference of indigenous vegetables in the Terai region (Shrestha and Sah, 2015). In contrast, hybrid vegetables are found to be low cost but high output varieties. Similarly, the policy of the government of Nepal has been promoting varieties that have high productivity as vegetables are kept under high priority for agriculture modernization (Timsina and Shivakoti, 2018).

\section{Biodiversity of vegetables}

Based on biodiversity measuring indices (Table 2), the hilly area was rich in OP vegetable diversity (3.3084) and terai in hybrids diversity (3.0086). The similarity among hill and terai was high for OP vegetables as compared to hybrids grown in two areas.

Table 2. Biodiversity of vegetables in the study area.
Rayo, Spinach, Garden cress, Fenugreek, Lettuce, Pigweed, Bokchoy and Swiss chard, while farmers of terai did not grow OP variety of capsicum but cultivated asparagus additionally in contrast to above crops. Similarly, the hybrid vegetables grown in terai were: Potato, Cabbage, Brinjal, Broccoli, Cowpea, Okra, Cucumber, Bitter gourd, Cauliflower, Pointed gourd, Pumpkin, Tomato, Carrot, Capsicum, Kohlrabi, Turnip, Beetroot, Snake gourd, Pea, Chilly, Bottle gourd, Radish, Bean, Sponge gourd, BLM and Bokchoy. In contrast, all but hybrid varieties of Snake gourd, Pea, Chilly, Bottle gourd, Radish, Bean, Sponge gourd, and Bok choy were not cultivated in hills.

\section{Sources of seed}

Most of the farmers in hilly areas were dependent on vegetable seeds produced by themselves (60) and neighbors (60), while in terai, most of them

\begin{tabular}{llllll}
\hline & Richness & $\begin{array}{c}\text { Biodiversity } \\
\text { Index }\end{array}$ & Evenness & $\begin{array}{c}\text { Effective Number } \\
\text { of Species (ENS) }\end{array}$ & $\begin{array}{c}\text { Sorenson's } \\
\text { co-efficient }\end{array}$ \\
\hline Biodiversity of OP vegetables in hills & 36 & 3.3084 & 0.9232 & 27.34 & 0.972 \\
Biodiversity of OP vegetables in terai & 36 & 3.2922 & 0.9187 & 26.90 & \\
Biodiversity of hybrid vegetables in hills & 16 & 2.588 & 0.9334 & 13.30 & 0.78 \\
Biodiversity of hybrid vegetables in terai & 25 & 3.0086 & 0.934 & 20.26 & \\
\hline
\end{tabular}


purchased from agro-concerns (48), followed by co-operatives (41) (Table 3). In both the territories, there was no facility of seed bank for seed conservation and supply to the farmers.

Table 3. Sources of seed used by farmers in the study area.

\begin{tabular}{lccc}
\hline \multirow{2}{*}{ Source of seed } & \multicolumn{2}{c}{$\begin{array}{c}\text { Number of } \\
\text { respondents }\end{array}$} & \multirow{2}{*}{$\begin{array}{c}\text { Chi-square } \\
\text { value }\end{array}$} \\
\cline { 2 - 3 } & Hills & Terai & \\
\hline Home storage & 60 & 16 & $69.474^{* *}$ \\
Neighbors & 60 & 12 & $80.000^{* *}$ \\
Cooperatives & 11 & 41 & $30.543^{* *}$ \\
Seed Banks & 0 & 0 & \\
Agro-concerns & 10 & 48 & $48.187^{* *}$ \\
\hline
\end{tabular}

In hilly areas, home storage of seeds helped to sustainably conserve vegetable diversity, commodification, and marketing of indigenous variety and knowledge (Tamagi, 2015).

\section{Role of ethnicity}

Gurung community (30) showed a significant role

\section{Plant protection}

The higher number of respondents mentioned that the incidence of diseases and insect pests was high in terai in both hybrids (44) and open-pollinated (18) vegetables as compared to hills (2 and 4, respectively). The majority of the farmers (52) did not grow hybrids in the hills (Table 5). Most of the respondents showed low disease in OP crops in hills (56) and terai (26) than in hybrids (6 and 9 in hills and terai, respectively). In terai, plants are more susceptible to insect pests due to high temperatures, high rainfall, high humidity, and saturated field conditions, which create favorable conditions for the infestation (Katsaruware et al., 2017).

\section{Use of pesticides and fertilizers}

Most of the respondents from terai used chemical pesticides (41) for control of diseases and insect pests in their vegetable crops, while a majority of the respondents from the hills used none (50) of the pesticides for the same purpose (Table 6). Similarly, chemical pesticides were used more in

Table 4. Role of ethnicity in biodiversity conservation.

\begin{tabular}{lcccc}
\hline Caste/Ethnicity & Hybrid & Open-pollinated & Both & Chi-square value \\
\hline Gurung & 0 & 30 & 5 & $27.11^{* *}$ \\
Newar & 0 & 3 & 1 & 1.2858 \\
Tamang & 3 & 3 & 5 & 3.14 \\
Magar & 3 & 9 & 3 & 2.81 \\
Chepang & 1 & 6 & 3 & 0.51 \\
Brahmin/Chhetri & 12 & 6 & 27 & $38.12^{* *}$ \\
\hline
\end{tabular}

Table 5. Incidence of diseases and insect pests in vegetable fields.

\begin{tabular}{llcccccc}
\hline \multirow{2}{*}{ Crop variety } & \multirow{2}{*}{ Belt } & \multicolumn{3}{c}{ Number of respondents } & \multirow{2}{*}{ Total } & \multirow{2}{*}{ Chi-square value } \\
\cline { 3 - 5 } & & High & Low & Not cultivated & & \\
\hline \multirow{2}{*}{ Hybrid } & Hill & 2 & 6 & 52 & 60 & $73.279^{* *}$ \\
& Terai & 44 & 9 & 7 & 60 & \\
\multirow{2}{*}{ Open-pollinated } & Hill & 4 & 56 & 0 & 60 & \multirow{2}{*}{$35.885^{* *}$} \\
& Terai & 18 & 26 & 16 & 60 & \\
\hline
\end{tabular}

for OP vegetable biodiversity conservation and Brahmin/Chhetri (12) for hybrid (Table 4). World Bank also explained the role of indigenous people crucial in biodiversity conservation of local crops interacting interdependently (FAO, 2012). hybrids (16), and most farmers none (53) in the open-pollinated vegetables. The majority of the farmers in terai grew hybrid vegetables, which are more prone to disease and insect pests. So, they use more chemical pesticides than farmers in the 
hills, which grew more nonhybrid vegetables.

Most of the farmers from hills (55) and terai (31) used organic manures for vegetable farming. However, a large number of farmers (24) from terai used both chemical and organic fertilizers (Table 6). Among the types of vegetables, OP vegetables were supplied with organic manures by most of the respondents (55), while hybrids were provided with chemical fertilizers by more farmers (5). Since hybrid varieties require more nutrients in a short time, chemical fertilizer is mostly used
The relationship among vegetable farming, co-operative membership, and support from organizations

The farmers (36) who received support from organizations, cultivated vegetables in more land area (5.431 ropani) than those (84) who were not getting any support from the organizations (1.012 ropani) (Table 7). The government organizations, farmers organizations, I/NGOs and communitybased organizations help in the development of value chain, accessibility of market, provision

Table 6. Use of pesticides and fertilizers by farmers in vegetable farming.

\begin{tabular}{|c|c|c|c|c|c|c|}
\hline \multirow{2}{*}{ Belt } & \multicolumn{4}{|c|}{ Number of respondents using pesticides } & \multirow{2}{*}{ Total } & \multirow{2}{*}{ Chi-square value } \\
\hline & Chemical & Organic & Both & None & & \\
\hline Hill & 4 & 4 & 2 & 50 & 60 & $53.935^{* *}$ \\
\hline Terai & 41 & 0 & 4 & 15 & 60 & \\
\hline \multicolumn{7}{|l|}{ Type of vegetable } \\
\hline Hybrid & 16 & 0 & 0 & 0 & 16 & $82.560 * *$ \\
\hline Open Pollinated & 1 & 4 & 1 & 53 & 59 & \\
\hline Both & 28 & 0 & 5 & 12 & 45 & \\
\hline Belt & \multicolumn{6}{|c|}{ Number of respondents using fertilizers } \\
\hline Terai & 5 & 31 & 24 & 0 & 60 & $30.03 * *$ \\
\hline Hill & 0 & 55 & 3 & 2 & 60 & \\
\hline \multicolumn{7}{|l|}{ Type of vegetable } \\
\hline Hybrid & 5 & 2 & 9 & 0 & 16 & $75.86^{* *}$ \\
\hline Open Pollinated & 0 & 57 & 0 & 2 & 59 & \\
\hline Both & 0 & 27 & 18 & 0 & 45 & \\
\hline
\end{tabular}

by hybrid variety growers (JICA, 2016). Another reason behind the less use of chemical fertilizers in the hills is low purchasing power and low availability of chemical fertilizers (Panta, 2018). of subsidies and technical support, which have a direct effect on increasing the land area under vegetable farming (Aku et al., 2018; UNDP, 2018). Similarly, the farmers who were involved

Table 7. Participation in organizations and land under vegetable farming.

\begin{tabular}{lcccc}
\hline Support from organizations & Response & Land (ropani) & Standard deviation & t- value \\
\hline Yes & 36 & 5.431 & 12.704 & $3.197^{* *}$ \\
No & 84 & 1.012 & 0.0656 & \\
Membership in co-operatives & & & & 1.871 \\
Yes & 74 & 3.297 & 9.058 & \\
No & 46 & 0.793 & 0.248 & \\
\hline
\end{tabular}


in co-operatives had grown vegetables in higher land areas, but the results were statistically nonsignificant.

Out of 60 respondents, 50 from Terai, and only 24 from hills had membership from cooperative (Table 7). There are a higher number of co-operatives in terai as compared to the hills of Nepal (Khatiwada and Rastra Bank, 2014). The awareness and interest in group formation and involvement in co-operative in hills are lower than in terai as the majority of people in hills are unaware of their needs and the benefits they could get from co-operatives. However, the support from organizations was higher in hills as compared to terai. Most of the I/NGOs have a significant focus on rural development (Dhakal, 2002) based organizations help in the development of value chain, accessibility of market, provision of subsidies and technical support, which have a direct effect on increasing the land area under vegetable farming (Aku et al., 2018; UNDP, 2018). Similarly, the farmers who were involved in co-operatives had grown vegetables in higher land areas, but the results were statistically nonsignificant.

\section{Significant problems in vegetable farming}

Lack of irrigation was the major problem in both the areas with the highest index value of 0.696 in terai and 0.683 in hills (Table 8), while climate change was ranked second with an index value of 0.667 in terai, but market unavailability in the hills (index value 0.658). The data shows that some problems have the same rank, and some are different depending on the geography of vegetable

Table 8. The Major problems in vegetable farming. farming. So, government and development organizations should focus on specific problems of each area for promoting vegetable farming. Development of vegetable farming value chain faces various constraints like irrigation, market, lack of input, and farming technology similar to the study of Thapa and Dhimal (2017).

\section{The market for vegetables in the study area}

Market access of the farmers/respondents to their produce was low (less than 40\%) in overall. However, it was more than double in terai than in hills in all market types. Farmers selling their products in farm gate were less than $20 \%$ in hills, while less than $40 \%$ in the terai (Figure 1), indicating the worse situation in hills than interai. It would be due to lack of transport, weak transport system, lack of cold storage, lack of market network, etc. especially in the hills.

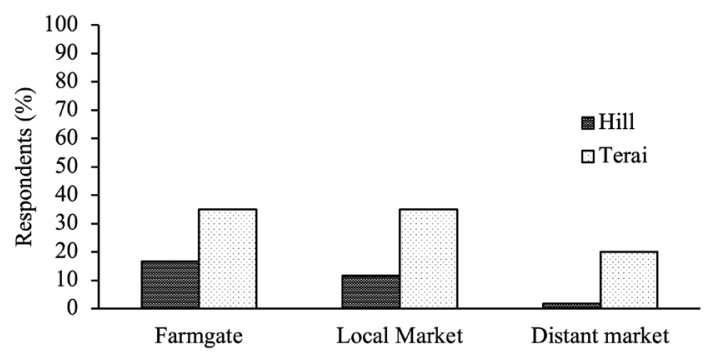

Fig.1.The response of the farmers/respondents for the marketing of their products in the study area.

The price determination for products was mostly done by the middlemen, and occasionally by the farmers themselves in both the areas. Interference and intervention of middle-man are seen more in the areas where there is access to large markets

\begin{tabular}{l|l|c|c|c|c|c|c|c}
\hline \multirow{2}{*}{ Belt } & \multirow{2}{*}{ Problem } & \multicolumn{4}{|c|}{ Ranking } & \multirow{2}{*}{ Weight } & Index & \multirow{2}{*}{ Rank } \\
\cline { 2 - 7 } & & 1 & 0.75 & 0.5 & 0.25 & & & \\
\hline Terai & Irrigation & 22 & 9.75 & 7.5 & 2.5 & 41.75 & 0.696 & I \\
& Climate change & 22 & 8.25 & 6 & 3.75 & 40 & 0.667 & II \\
& Market & 11 & 21 & 5.5 & 2.25 & 39.75 & 0.663 & III \\
\cline { 2 - 6 } Hills & Farming technology & 5 & 6 & 11 & 6.25 & 28.25 & 0.471 & IV \\
& Irrigation & 18 & 8.25 & 14 & 0.75 & 41 & 0.683 & I \\
& Market & 20 & 12.75 & 2 & 4.75 & 39.5 & 0.658 & II \\
& Farming technology & 10 & 12 & 9 & 4 & 35 & 0.583 & III \\
& Climate change & 12 & 12 & 5 & 5.5 & 34.5 & 0.575 & IV \\
\hline
\end{tabular}


(Mitchell, 2011). Mediators pay a low price to farmers and seek high payment from traders (Pokhrel, 2010). Due to the middlemen's' syndicate system, if farmers directly try to sell their produce in the market, they become unable to get the place in the market (SNV and IFAD, 2011; Rai et al., 2019). It directly hampers the practice and mindset of the farmers towards vegetable farming, which in turn affects the biodiversity of vegetables.

\section{Off-farm vegetable collection}

Off-farm vegetable collection means a collection of naturally grown, edible, wild vegetables for their home consumption or marketing to earn money. In some places, it may be a good practice to supply nutritious vegetables during a lean period and to earn some money as well. Most of the farmers/respondents (58) from hills practiced off-farm vegetable collection, but on the contrary, most farmers (55) from terai did not do it (Table 9). Higher practice in the hills would be due to higher diversity of wild vegetables and humid microclimate around the year suitable for vegetable growth wildly in the hills than in terai.

Table 9. Practice of off-farm vegetable collection in the study areas.

\begin{tabular}{lccc}
\hline \multirow{2}{*}{ Belt } & \multicolumn{2}{c}{ Number of respondents } & \multirow{2}{*}{ Total } \\
\cline { 2 - 4 } & Yes & No & \\
\hline Hill & $58\left(96.67^{*}\right)$ & $2(3.33)$ & 60 \\
Terai & $5(8.33)$ & $55(91.67)$ & 60 \\
Total & $63(52.5)$ & $57(47.5)$ & 120 \\
\hline
\end{tabular}

*percentage

\section{Conclusion}

The study revealed that open-pollinated (OP) vegetables were more diverse in hills than in terai, while hybrid vegetables were more diverse in terai than in hills. Even higher land area under diverse OP vegetable farming was found in hills than in terai. Due to the use of hybrid vegetables, more use of agrochemicals appeared in terai than in hills. However, conservation of $\mathrm{OP} /$ nonhybrid vegetable germplasm was higher in hills than in terai, but at household levels. The off-farm vegetable collection was also typical in hills. Organizational support was also high in hills, which had a significant role in promoting vegetable farming, while co-operatives were more common in terai. Significant problems in vegetable diversity conservation and commercialization were irrigation, market access, climate change, and inadequate production technologies in both regions. Vegetable diversity conservation and commercialization seem to be crucial, and the government should have good policy toward mitigation of climate change, infrastructure development, such as irrigation, gene bank establishment, cold storage development and marketing of products, and technology transfer, for wild and cultivated vegetable diversity conservation and expansion of commercialization of the vegetables.

\section{Reference}

Aku, A., P. Mshenga, V. Afari-Sefa, and J. Ochieng. 2018. Effect of market access provided by farmer organizations on smallholder vegetable farmer's income in Tanzania. Cogent Food and Agriculture. 4:560-596.

Biala, K., A. Peeters and B.Muys. 2005. Biodiversity indicators as a tool to assess sustainability levels of agro-ecosystems, with special consideration of grassland areas. Options Méditerranéennes. SérieA: SéminairesMéditerranéens. 67: 439-443.

Dhakal, T. N., 2002.The Role of Non-Governmental Organizations in the Improvement of Livelihood in Nepal.

FAO. 2012. Agricultural cooperatives: paving the way for food security and rural development Cooperatives : a pillar for agricultural development and food security.

Frison, E. A., J. Cherfas, and T. Hodgkin. 2011. Agricultural biodiversity is essential for a sustainable improvement in food and nutrition security. Sustainability.3: 238-253.

IBD. 2008. Biodiversity and Agriculture Safeguarding Biodiversity and Securing Food for the World International Day for Biological Diversity.

JICA. 2016. Vegetable Farming Techniques Manual. Pp. 1-138.

Katsaruware, R., P. Mafongoya, and A. Gubba. 2017. Responses of Insect Pests and Plant Diseases to Changing and Variable Climate: A Review. Journal of Agricultural Science.9.

Khatiwada, Y. R. 2014.Cs from Nepal. Pp. 1-23.

Love, B., and D. Spaner. 2007. Agrobiodiversity: Its value, measurement, and conservation in the context of sustainable agriculture. Journal of 
Sustainable Agriculture. 31: 53-82.

Mitchel, T., 2011. Middlemen, Bargaining, and Price Information: Is knowledge Power? London School of Economics and Political Science. Pp. 1-43.

Panta, H. K., 2018. Supply Chain of Subsidized Chemical Fertilizers in Nepal. Journal of the Institute of Agriculture and Animal Science. 35: 9-20.

Pokhrel, D. M., 2010. Comparison of Farm Production and Marketing Cost and Benefit.The Journal of Agriculture and Environment. 11: 10-25.

Rai, M. K., P. Nepal, D.B. Rai, and B. Paudel, 2019. Commercial vegetable farming: Constraints and opportunities of farmers in Kirtipur, Nepal. Geographical Journal of Nepal. 12: 101-118.

Shrestha, S., and R. Sah. 2015. Evaluation of Tomato Cultivars for Central Tarai of Nepal. Nepal Journal of Science and Technology, 15: 11-16.

SNV and IFAD. 2011. Value Chain Analysis of OffSeason Vegetables (OSV). 66: 37-39.

Tamagi, B., 2015. Assessing Local Practices of Organic Vegetable Production.Pp. 132-141.

Thapa, M. B., and S. Dhimal. 2017. Horticulture Development in Nepal: Prospects, Challenges, and Strategies. Univers. J. Agric. Res. pp.: 177 - 189.

Timsina, K., and G.Shivakoti. 2018. Vegetable production and marketing: Practice and perception of vegetable seed producers and fresh growers in Nepal. Agriculture and Food Security.

UNDP. 2018. Value Chain Development of Fruit and Vegetables in Nepal. Project document.UNDP, Nepal.

UNEP. 2010. Biodiversity: Our Life. Our Planet- May. 